\title{
Strength Degradation of Sapphire Fibers During Pressure Casting of a Sapphire-Reinforced Ni-Base Superalloy
}

Rol/hostl|tlaipaand additional works at: https://engagedscholarship.csuohio.edu/encbe_facpub

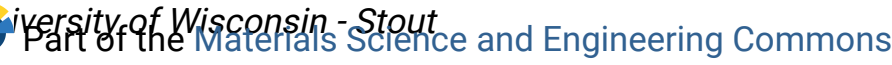

slorentpasạcewarto this work benefit you? Let us know!

Penslistheta'stimesiment

Eopyright 1998 ASM International. This paper was published in Metallurgical and Materials

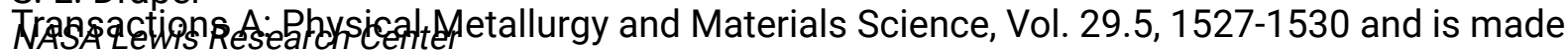
available as an electronic reprint with the permission of ASM International. One print or electronic copy may be made for personal use only. Systematic or multiple reproduction, distribution to multiple locations via electronic or other means, duplications of any material in this paper for a fee or for commercial purposes, or modification of the content of this paper are prohibited.

Available on publisher's site at: http://www.asminternational.org/portal/site/www/AsmStore/ ProductDetails/?vgnextoid=743cc777b3426210VgnVCM100000621e010aRCRD.

\section{Original Citation}

Asthana, R., Tewari, S.N., \& Draper, S.L. (1998). Strength Degradation of Sapphire Fibers During Pressure Casting of a Sapphire-Reinforced Ni-Base Superalloy. Metallurgical and Materials Transactions A: Physical Metallurgy and Materials Science 29, 1527-1530.

Repository Citation

Asthana, R.; Tewari, Surendra N.; and Draper, S. L., "Strength Degradation of Sapphire Fibers During Pressure Casting of a Sapphire-Reinforced Ni-Base Superalloy" (1998). Chemical \& Biomedical Engineering Faculty Publications. 15.

https://engagedscholarship.csuohio.edu/encbe_facpub/15

This Article is brought to you for free and open access by the Chemical \& Biomedical Engineering Department at EngagedScholarship@CSU. It has been accepted for inclusion in Chemical \& Biomedical Engineering Faculty Publications by an authorized administrator of EngagedScholarship@CSU. For more information, please contact library.es@csuohio.edu. 
and liquid free energies at either temperature. The author acknowledges that the inclusion of these dotted lines could lead to such confusion on the readers' part, but this fact in no way invalidates the theory presented.

\section{Strength Degradation of Sapphire Fibers during Pressure Casting of a Sapphire-Reinforced Ni-Base Superalloy}

\section{R. ASTHANA, S.N. TEWARI and S.L. DRAPER}

IT is well known that solid-state techniques ${ }^{[1-6]}$ of fabricating high-temperature fiber-reinforced superalloys and intermetallics suffer from the problems of interface contamination from binder residues and oxides on metal powders. Liquid-phase fabrication using pressure casting of fiber-reinforced Fe- and Ni-base intermetallics ${ }^{[7,8]}$ offers flexibility in designing matrix and interface structures. Improvement in wettability by alloying ${ }^{[9]}$ or application of pressure ${ }^{[7,8]}$ is required to manufacture structurally viable defect-free composite castings. Relatively little work has been reported in the literature on liquid-phase fabrication of ceramic fiberreinforced superalloys. In a recent study on pressure-cast alumina fiber-reinforced superalloy (INCONEL* 718) com-

*INCONEL is a trademark of INCO Alloys International, Inc., Huntington, WV.

posites, Nourbakhsh et al. ${ }^{[10]}$ reported formation of a strong interfacial bond, with a bond strength in excess of 150 $\mathrm{MPa}$, between single crystal sapphire fibers and the superalloy matrix. It was stated that the high ductility of the matrix, approximately $20 \mathrm{pct}$, together with a strong interfacial bond, would yield a strong composite material provided that the fibers are not degraded during composite fabrication. A detailed microscopic characterization of the composite was carried out. However, metallography of fiber-matrix interface may not reveal the extent of fiber degradation during fabrication.

The purpose of this study was to prepare sapphire fiberreinforced superalloy matrix composites using pressure infiltration casting, extract the fibers from the composite, and measure the room-temperature strength to determine the extent of fiber damage due to pressure infiltration casting. The superalloy (Hastelloy) selected for the present study $(47.5 \mathrm{Ni}, 21.5 \mathrm{Cr}, 17.8 \mathrm{Fe}, 8.3 \mathrm{Mo}, 1.7 \mathrm{Co}, 0.3 \mathrm{Mn}, 0.4 \mathrm{Si}$, $0.2 \mathrm{Al}, 0.1 \mathrm{Cu}, 0.4 \mathrm{Nb}, 0.06 \mathrm{Ti}, 0.08 \mathrm{C}$, and $0.02 \mathrm{O}$, in wt pet.) is very similar to the INCONEL 718 superalloy used by Nourbakhsh et al. ${ }^{[10]}$ Single crystal sapphire fibers (c-axis oriented, nominal diameter: $130 \mu \mathrm{m}$ ) from Saphikon Inc. (Milford, CT) ${ }^{[11]}$ were used as the reinforcement. Initial tri-

R. ASTHANA, Assistant Professor, is with the Manufacturing Engineering Program, Technology Department, University of WisconsinStout, Menomonie, WI 54751. S.N. TEWARI, Professor, is with the Chemical Engineering Department, Cleveland State University, Cleveland, OH 44115. S.L. DRAPER, Materials Research Engineer, is with the Materials Division, NASA Lewis Research Center, Cleveland, OH 44135. Manuscript submitted September 10, 1996.

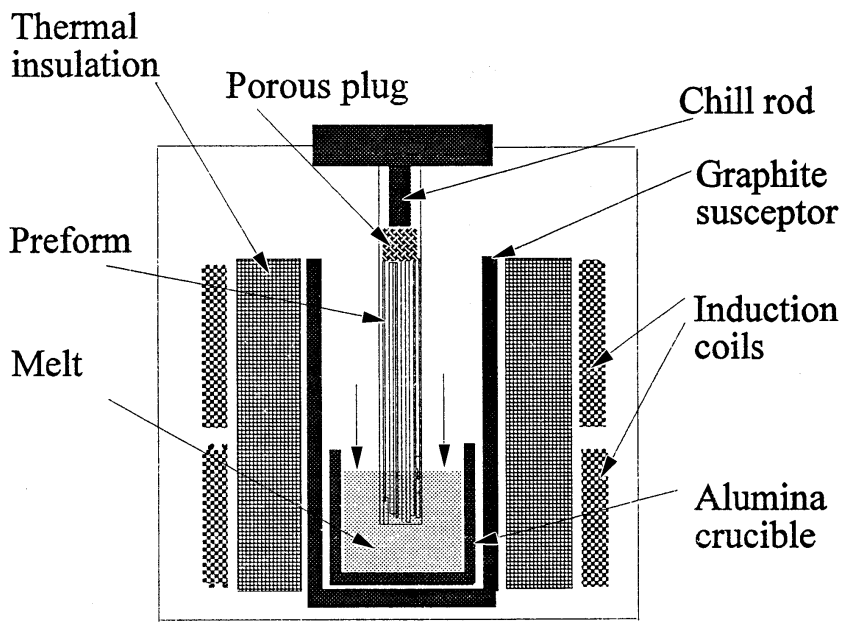

(a)

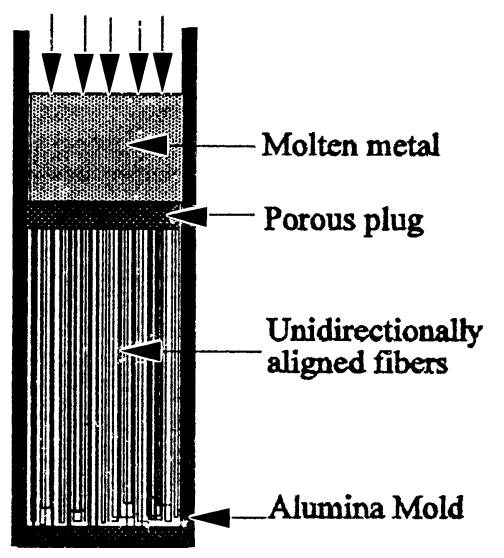

(b)

Fig. 1-Infiltration configurations used in pressure casting of sapphirehastealloy composites: (a) bottom-fill infiltration and (b) top-fill infiltration.

als to make sapphire-superalloy composites using vacuum infiltration in a countergravitational configuration were unsuccessful. The pressure infiltration casting was performed in a specially designed pressure chamber that housed a pair of induction coils, powered with a generator, to independently heat the preform and the metal. Infiltration was effected in either bottom-fill or top-fill configuration (Figure 1). Preforms with unidirectionally aligned sapphire fibers were made by tightly packing fibers in a recrystallized alumina mold. A total of 23 separate infiltration tests were conducted for optimizing the fabrication procedure. The temperatures of the preform and the metal were monitored with the help of tungsten-rhenium thermocouples that were calibrated against the melting point of high purity nickel. The infiltration procedure consisted of setting up the preform and charge in the desired configuration (Figure 1), installing the thermocouples in the metal and the preform, closing the pressure vessel, and purging the chamber with ultrahigh purity argon to a vacuum level of about $10^{-3}$ torr. The preform and the metal charge were heated simultaneously but independently. Once the desired temperatures were reached, the vessel was pressurized with argon gas to effect infiltration. At the conclusion of infiltration, the chamber was purged with argon to cool the sample. In order to feed the metal shrinkage that forms during solidification, 


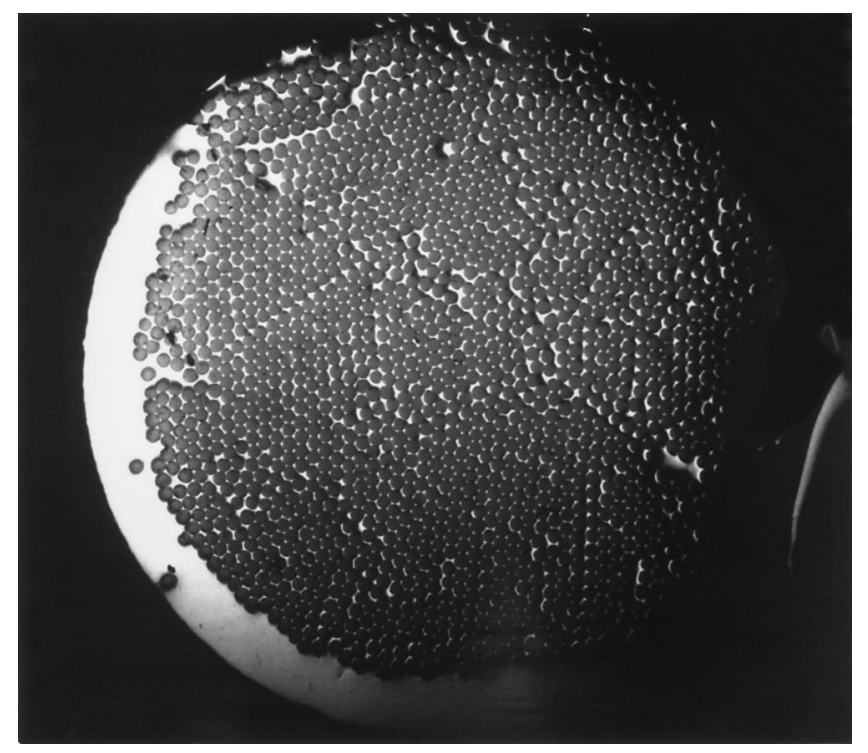

(a)

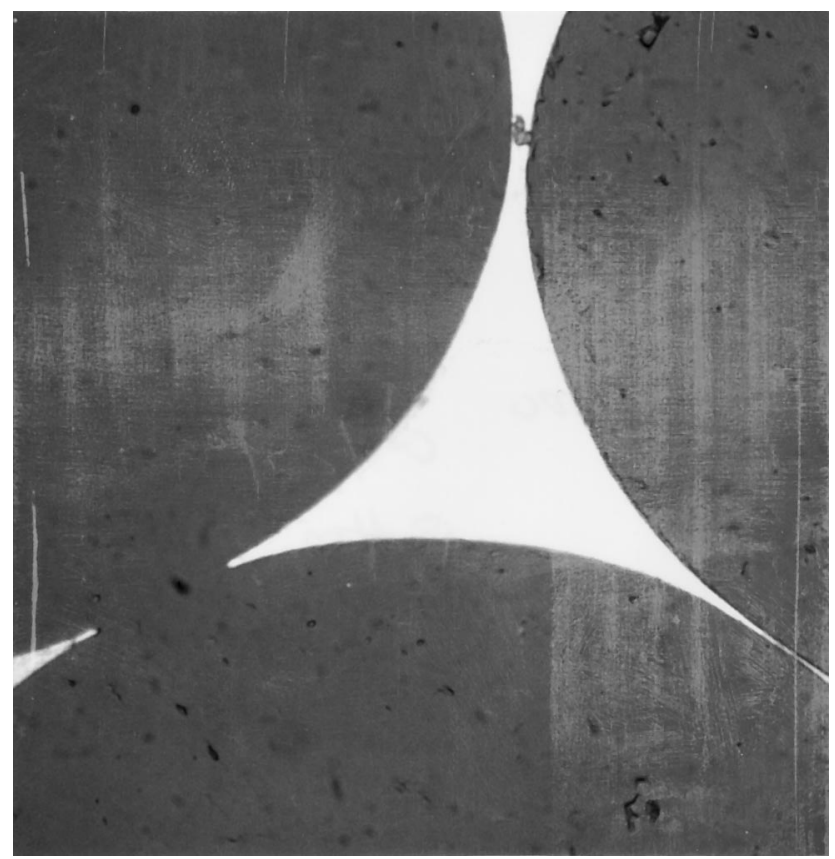

(c)

the path of solidification front must be carefully guided. In top-fill infiltration, solidification should start from the bottom and proceed toward the top so that shrinkage is continuously fed by the metal. In order to ensure this, a thick chill plate was placed in contact with the lower (closed) end of the alumina mold.

Fibers from pressure-cast sapphire-Hastealloy composites were extracted by dissolving the matrix in a solution of $75 \mathrm{~mL}$ acetic acid (glacial), $25 \mathrm{~mL}$ concentrated nitric acid, and $2 \mathrm{~mL}$ concentrated hydrochloric acid. Strength measurements were made on extracted fibers using an Instron frame. A gage length of $1.27 \times 10^{-2} \mathrm{~m}$, a grip distance of $0.114 \mathrm{~m}$, and a crosshead speed of $1.27 \times 10^{-3}$ $\mathrm{m} \cdot \mathrm{min}^{-1}$ were used.

Figure 2 shows a typical microstructure of sapphire-Hastealloy composite made under optimum pressure casting con-

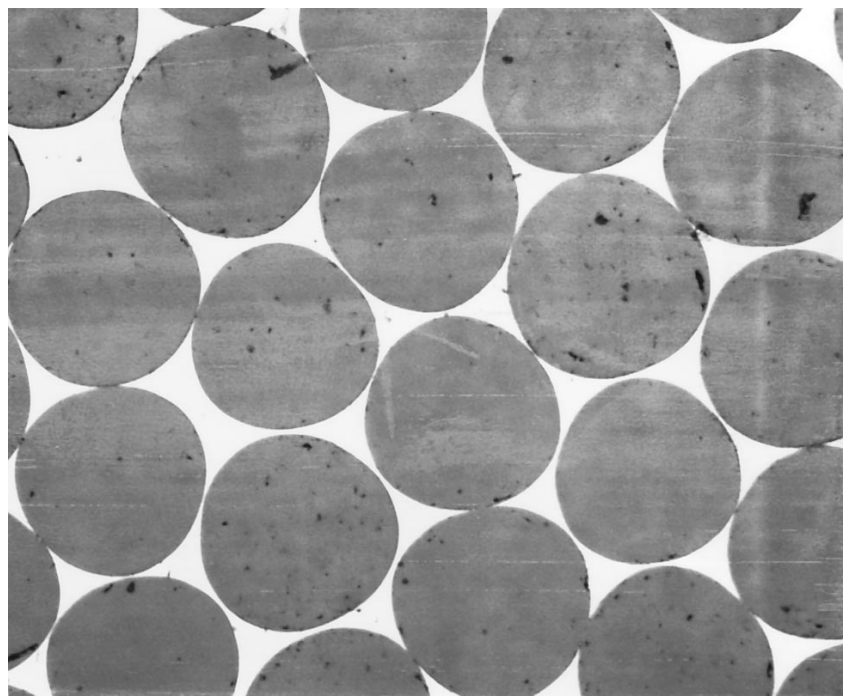

(b)

Fig. 2-Photomicrographs of (a) transverse sections near the bottom portion of pressure-cast sapphire-Hastealloy composites made using the top-fill infiltration of preforms made from densely packed sapphire fibers; and $(b)$ and $(c)$ a sample from (a) showing good penetration by melt of narrow interfiber regions.

ditions. The experiments in the countergravitational (bottom-fill) configuration generally led to unsound castings (fiber clumping, bent casting) and/or shorter infiltration lengths. The microstructure of infiltrated bars showed fiberto-fiber contact, large uninfiltrated regions, and porosity. In top-fill infiltration experiments, infiltration was always successful. Good penetration of interfiber regions and limited fiber-to-fiber contact were observed (Figure 2).

Postinfiltration cooling rate was a critical parameter, a rapid surge of argon gas led to mold cracking, loss of interdendritic liquid from partially solid casting, and/or stress cracks in the casting. This could be avoided by a controlled decrease of power (slow cooling) to a temperature range of $800{ }^{\circ} \mathrm{C}$, followed by a blast of cold gas that brought the sample temperature close to ambient. In the top-fill configuration, infiltration was less sensitive to the rate of pres- 


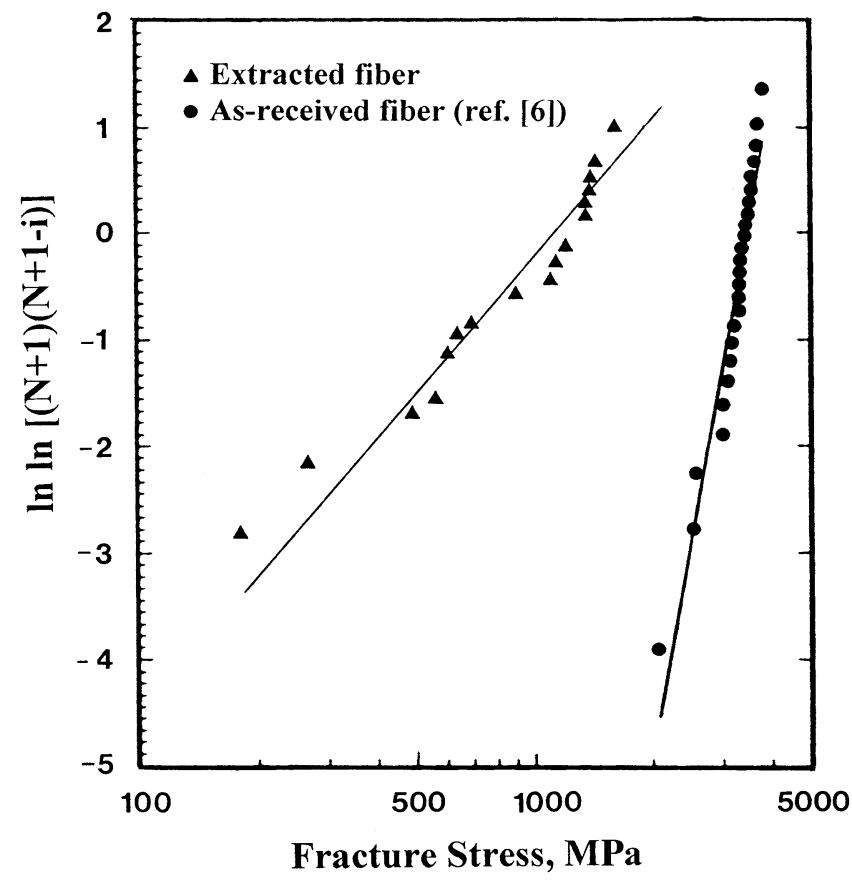

Fig. 3-Weibull plots of distribution of room-temperature tensile strength of as-received sapphire fibers, and fibers extracted from pressure-cast sapphire-Hastealloy composites. Mean Weibull strength: $904 \mathrm{MPa}$; standard deviation: $562 \mathrm{MPa}$; and coefficient of variation: 62 pct. Test conditions: crosshead speed: $0.00127 \mathrm{~m}$ per min; and gage length: $0.0127 \mathrm{~m}$.

surization; slow, fast, and stepped (interrupted) pressurization all yielded good infiltration. However, with bottom-fill infiltration, fast pressurization usually led to mold cracking and loss of pressure differential; only slow or stepped infiltration (in steps of about 12 psi per second) prevented mold cracking during infiltration. Rapid pressurization also tends to chill the metal surface, thereby making infiltration more difficult to accomplish.

The regions where fibers were packed tightly with small interfiber spacings showed little fiber damage. However, in regions where a relatively large pool of metal was in contact with the fibers, significant fiber damage was observed. This attack may be due to a strong chemical reaction between sapphire and reactive solutes such as chromium in the alloy. The energy dispersive spectroscopic examination of extracted fibers showed the presence of $\mathrm{Cr}$ on fiber surface. Chemical reactions between chromium and alumina have also been reported in other studies. ${ }^{[12,13]}$

The strength measurements on extracted sapphire fibers show that fibers suffered a severe loss of strength. The extracted fibers were very brittle and difficult to handle. The fiber strength data were analyzed using a two-parameter Weibull distribution function of the form ${ }^{[14]}$

$$
F(\sigma)=1-\exp \left(\alpha \sigma^{\beta}\right)
$$

where $F(\sigma)$ is the probability of failure of a fiber of strength $\sigma(=i / N+1$, where $N$ is the sample population and $i$ is the $i$ th fiber when strength data are arranged in ascending order), $\alpha$ is the scale parameter, and $\beta$ is the Weibull modulus. The distribution of fiber strength follows a Weibull distribution if a plot of $\ln \ln ((N+1) /(N+1-i)) v_{s} \ln$ $\sigma$ is linear. Figure 3 compares Weibull plots of strength distribution of sapphire fibers extracted from the superalloy with the strength distribution of as-received fibers. The experimental strength data appear to follow a Weibull distribution function. A least-squares fit of the data yielded the equation of straight line as $y=1.7479 \times-12.0997$. The values of $\alpha$ and $\beta$ are $5.561 \times 10^{-8}$ and 1.7479 , respectively. The Weibull mean strength, $\sigma$, standard deviation, $s$, and coefficient of variation, $\mathrm{CV}$, were estimated from the following relationships:

$$
\begin{gathered}
\sigma=\alpha^{-\frac{1}{\beta}} \Gamma\left(1+\frac{1}{\beta}\right) \\
s=\alpha^{-\frac{1}{\beta}}\left[\Gamma\left(1+\frac{2}{\beta}\right)-\Gamma^{2}\left(1+\frac{1}{\beta}\right)\right]^{1 / 2} \\
\mathrm{CV}=100\left(\frac{s}{\sigma}\right)
\end{gathered}
$$

Here, $\Gamma$ is the Gamma function. The values of $\sigma, s$, and $\mathrm{CV}$ are $904 \mathrm{MPa}, 562 \mathrm{MPa}$, and $62.2 \mathrm{pct}$, respectively. There was, on average, 66 pct decrease in fiber strength after casting; the as-received fiber strength was about 2.7 $\mathrm{GPa},{ }^{[1]}$ whereas the strength of extracted fibers (average of 17 tests) was $0.904 \mathrm{GPa}$ (Figure 3). Extensive chemical attack of polycrystalline as well as single crystal alumina fibers also has been noted in pressure-cast and powder-processed Fe- and Ni-base intermetallic-matrix composites. ${ }^{[7,8]}$ The degradation of strength of single crystal sapphire (SAPHIKON Inc.) fibers in "powder-cloth" processed Fe$\mathrm{CrAlY}, \mathrm{FeCrAl}, \mathrm{Cr}, \mathrm{FeAl}$, and $\mathrm{NiAl}$ matrix composites is in the range of 45 to 60 pct, ${ }^{[5,6]}$ whereas strength degradation in pressure-cast $\mathrm{Ni}_{3} \mathrm{Al}$-Ti matrix composites is reported to be 67 pct. ${ }^{[8]}$ The distribution of fiber strength in these composites was reported to be consistent with Weibull statistics. The scanning electron microscopic examination of fibers extracted from the pressure-cast Hastealloy specimens showed clear evidence of surface damage due to chemical reactions. The scale of the surface damage (notches) appears to be appreciably greater than the estimated critical flaw size of about $0.18 \mu \mathrm{m}$ for as-received single crystal sapphire fibers. ${ }^{[5]}$ As the matrix chemistries of Hastealloy used in the present study and the INCONEL 718 alloy used by Nourbakhsh et al. ${ }^{[10]}$ are not very different, it is apparent that in spite of high strength of the interfacial bond and large ductility of the superalloy matrix, the damaged sapphire fibers are not likely to yield the expected strength advantage of fiber-reinforced superalloy matrix composites. A judicious selection of matrix alloy chemistry, use of reaction barrier coatings, and control of processing conditions (e.g., lower temperatures) will likely promote wetting and interfacial bonding while minimizing extensive degradation of reinforcement strength from chemical attack.

\section{ACKNOWLEDGEMENT}

Appreciation is expressed to C. Palda, D. Koty, and M. McQuater for technical assistance at various stages of this work. The continuous encouragement and support from T.K. Glasgow, Chief, Processing Science and Technology Branch, Lewis Research Center, are gratefully acknowledged. One of the authors (RA) acknowledges 
support received from the National Research Council (Washington, DC), and the University of WisconsinStout. Appreciation is also expressed to Professor S. Nourbakhsh for sharing with us the design of his pressure infiltration casting setup.

\section{REFERENCES}

1. J. Sorensen: in Structural Intermetallics, R. Darolia, J.J. Lewandowski, C.T. Liu, P.L. Martin, D.B. Miracle, and M.V. Nathal, eds., TMS, Warrendale, PA, 1993, p. 717.

2. R.D. Noebe, R.R. Bowman, and J.I. Eldridge: Intermetallic Matrix Composites, Materials Research Society Symposia Proceedings, D.L. Anton, R. McMecking, D. Miracle, and P. Martin, eds., Materials Research Society, Pittsburgh, PA, 1990, vol. 194, p. 323.

3. J.W. Pickens, R.D. Noebe, G.K. Watson, P.K. Brindley, and S.L. Draper: NASA TM 102060, NASA, Washington, DC, 1989.
4. S.L. Draper, D.J. Gaydosh, and M.V. Nathal: J. Mater. Res., 1990, vol. 5, p. 1976.

5. S.L. Draper and I.E. Locci: J. Mater. Res., 1994, vol. 9 (6), p. 1397.

6. R.R. Bowman, I.E. Locci, S.L. Draper, and A.K. Misra: Materials Research Society Symposia Proceedings, Materials Research Society, Pittsburgh, PA, 1994, vol. 350, p. 105.

7. S. Nourbakhsh, O. Sahin, W.H. Rhee, and H. Margolin: Metall. Trans. A, 1991, vol. 22A, pp. 3059-64.

8. S. Nourbakhsh, O. Sahin, W.H. Rhee, and H. Margolin: Metall. Mater. Trans. A, 1994, vol. 25A, pp. 1259-65.

9. D. Xu, D. Wang, and T.L. Lin: Scripta Metall., 1993, vol. 26, p. 599.

10. S. Nourbakhsh, O. Sahin, W.H. Rhee, and H. Margolin: Metall. Mater. Trans. A, 1996, vol. 27A, pp. 451-58.

11. "Sapphire and Advanced Single Crystal Technologies" (Data Sheet), Saphikon Inc., Milford, NH, 1993.

12. P. Kritsalis, V. Merlin, L. Coudurier, and N. Eustathopoulos: Acta Metall. Mater., 1992, vol. 40 (6), p. 1167.

13. P. Kritsalis, J.G. Li, L. Coudurier, and N. Eustathopoulos: J. Mater. Sci., 1990, vol. 9, p. 1332.

14. K.K. Chawla: Composite Materials-Science and Engineering, Springer-Verlag, New York, NY, 1987. 